\title{
The Impact of Cooperation on Firms' Innovation Propensity in Emerging Economies
}

\author{
Serdal Temel',Anne-Laure Mention², Marko Torkkeli ${ }^{3}$
}

\begin{abstract}
The importance of collaboration has been one of the main issues in innovation studies. Despite many different findings on collaboration and its impact on innovation performance, the impact of different types of collaboration on different types of innovation is still inconclusive. The purpose of this research is to investigate the effects of openness on the performance of the innovation process in a leading emerging economy. Cooperation with partners and their effects on innovation propensity unveil that process, marketing and organisational innovations are determinants of product and service innovation, thus confirming that the various innovation types are intertwined and mutually supporting each other. From a geographical perspective, cooperating with external parties from the same country plays a dominant role in determining the innovation outcome. Cooperating with consultants and private labs on the other hand seems to negatively affect innovation performance. Surprisingly, the role of foreign cooperation remains ambiguous as results were not statistically significant.
\end{abstract}

Keywords: open innovation, performance, cooperation, emerging and transition economies.

\footnotetext{
' Ege University Science and Technology Centre, 35100 Bornova, Izmir-Turkey. Phone : +90 232343 4400. email: serdal.temel@ege.edu.tr. ${ }^{2}$ Centre de Recherche Public Henri Tudor, 29 Avenue J.F. Kennedy, 1855 Luxembourg, Luxembourg.

${ }^{3}$ Department of Industrial Engineering and Management, Lappeenranta University of Technology, P.O. Box 20, FIN-5385I Lappeenranta, Finland.
} 


\section{Introduction}

The Schumpeterian mode (Schumpeter, 1942) of the individual entrepreneur, which embraces sequentially the 3 stages of invention (i.e. research leading to the generation of new ideas), innovation that involves the development of these new ideas into marketable products and finally, the diffusion process across the market, has been challenged by new models emphasizing the interactive nature of the innovation process. According to those models, turning an idea into a potentially successful product or service requires the cooperation between multiple players, usually coming from various disciplinary horizons. Along these lines, innovations have been acknowledged to result from interactions between individuals, teams, groups located both and outside the boundaries of the firm, as already strongly emphasized in the third generation of innovation model (Rothwell, 1992). Despite the growing awareness of these open, networked and interactive features of the innovation process, there is so far little empirical evidence on the impact of opening up the innovation process on performance, either considered in economic terms or adopting a broader approach to performance, which encompasses financial and non financial criteria, and thus this represents a critical area of interest for innovation management.

Lichtenthaler (20II) further posits that prior research has only touched upon the impact assessment of the openness feature of the innovation process on performance, especially from a quantitative perspective. This observation echoes the findings of Dahlander and Gann (20I0), whose recent systematic literature review indicates that large-scale quantitative studies remain scarce, with some notable exceptions such as Laursen and Salter (2006) and Van de Vrande et al. (2009), and Mention and Asikainen (2012) in service economies. Furthermore, most of prior studies have focused on developed economies (e.g. Tether, 2005) and neglected transition and developing economies.

This empirical study precisely aims to investigate the effects of openness on the innovation process and on its performance in a leading emerging economy. More specifically, it first investigates how cooperation affects innovation propensity, measured as the introduction of novelties, either in the forms of goods or services. Then, it further delineates the influence of the geographical location of the cooperating partner, as well as the type of partner on the innovative performance. Finally, it considers how cooperating affects the degree of novelty of the innovation introduced.

The article has the following structure. After this introductory section, the article presents the framework conditions for innovation and collaboration taking into consideration the specific Turkish context. In the third section, the theo- retical background of innovation collaboration is developed and 7 hypotheses on collaboration based strategy are formulated. Section 4 describes our research methods and data collection. The hypotheses are tested through logistic regression analysis and discussed in section 5 . Finally, findings are presented in section 6 , which also discusses their managerial implications together with recommendations for policy makers.

\section{Framework conditions for Innovation and Collabo- ration in Turkey}

Most of the developing countries had protectionist policies until 1980's and during those periods these policies did not create any meaningful reason for the firms to focus more on R\&D and innovation and collaboration (Mookherjee and Ray, I99I; Kabiraj and Yang, 200I). Thereafter gradually, many developing countries shifted from protectionist period to competitive environment in order to enhance competitiveness of their firms and country accordingly. Turkey is not an exception to this shift.

Since the liberalization of its economy in the early 1980s, Turkey has put significant emphasis on innovation and collaboration for innovation, mostly with universities, with the objective of enhancing the competitiveness of the small and medium-sized enterprises (SMEs) (Pamukcu, 2003; Cetindamar and Ulusoy, 2008). After the liberalization of the economy, Turkish firms have faced increasing international competition, which made innovation and university-industry collaboration more important (Pamukcu, 2003), and several public institutions, including The Directorship for Small and Medium-Sized Enterprises (KOSGEB), Directorship for Technology and Innovation Assessment (TEYDEB) and Technology Development Foundation of Turkey (TTGV), were established in mid-1990s to facilitate innovation (Beba and Saatcioglu, 2009; Turkoglu and Celikkaya, 20II).

After 1994, consecutive Turkish governments launched programs, introduced incentives and founded organizations to support and encourage firms (mostly SMEs) to perform better regarding innovation (Yaniktepe and Cavus, 20II). These institutions are designed to help and guide firms in developing their own innovation projects, providing financial support through various programs. The ultimate aim of these support programs is to enhance the firms' innovative capacity trough innovation projects and collaboration with external organizations such as universities, research centres and other service providers.

Although, compared to most European countries, Turkey implemented support programs relatively late; however the development of its innovation infrastructures has been extraordinary. This is reflected by the rate of R\&D-oriented 
companies, which gradually grew from around $1 \%$ to $1.4 \%$ in 1995, and public R\&D support funds increased substantially, to $2.1 \%$ in 1997 and $2.5 \%$ in 2000 (Taymaz, 2009). The main objective of those support programs is to enhance innovativeness of companies either alone or together with research centres.

Notwithstanding most Turkish SMEs are still labour-intensive and produce low value-added products, their focus on innovation (Cetindamar and Ulusoy, 2008) and cooperation is increasing. Turkey is one of the fastest growing economies when it comes to R\&D and innovation, and the number of firms that has the potential to collaborate with external partners is increasing continually, which is why the Turkish situation provides us with an opportunity to examine the early effects of innovation-based strategy and external cooperation on firm performance.

\section{Theoretical background and Hypotheses}

Literature on the rationales for cooperation in innovation activities abounds and usually distinguishes inter-firm cooperation, intra-firm, intra-country cooperation and cooperation with research institutions. Inter-firm cooperation has been demonstrated to support firms in their achievement of three complementary goals. First, it contributes to the creation of a critical mass of resources that enhance firms' capacity to handle more complex and more demanding ventures. Mairesse and Mohnen (200I) confirm the positive relationship between R\&D spending and innovation performance using the French CIS 2. Similarly, the share of R\&D resources for in-house R\&D and the number of R\&D staff have been demonstrated as the main factors of innovation performance in most studies (e.g. Griliches, 1990; Crépon et al., 1998); therefore these items have become important variables in the explanation of innovation performance. This critical mass of resources may be a consequence of a combination of similar resource bases, through resource pooling or may be derived from the bundling of unique repositories of skills, expertise and knowledge of individual firms. Second, it enables firms to rely on counterpart's resources and achieve higher levels of agility and flexibility in the distribution of tasks both within and across different yet common projects. Finally, through their partners' networks, firms can indirectly extend their own pool of potential resources and partners.

There are different numbers of researches which have emphasised the impact of external R\&D cooperation on firm's innovation performance (e.g. Lööf and Heshmati, 2002; Miotti and Sachwald, 2003; Cincera et al., 2003; Belderbos et al., 2004; Lööf and Broström, 2008; Aschhoff and Schmidt, 2006). The benefits of co-operation have been extensively studied and summarized by Ahuja (2000): endure environ- mental shocks, improve economic performance and likelihood of survival, gain access to complementary resources, learn new skills, absorb technology, have control over relation with other companies, keep abreast with competitors and improve efficiency. Moreover, access to technology bases through inter-firm co-operation or alliance has been demonstrated to help companies to redefine and reposition themselves in the market in terms of technology.

Co-operation for innovation is also often motivated by the willingness to gain access to new or foreign markets and to share the risks and costs associated with R\&D and innovation activities. Critical factors for successful co-operation agreements have been identified in strategic alliance literature and include trust, communication, matching of resources, organizational structures and processes (George and Farris, 1999). Besides the adequacy of this matching, the ability of firms to keep and maintain the skills balance is another key success factor (Hanna et al., 2008). The potential of firms to generate innovations is dependent on the prior accumulation of knowledge they have absorbed (Fiol, 1996), in line with the concept of "absorptive capacity" introduced by Cohen and Levinthal (1989).

Inter-firm cooperation also embraces co-opetition (Brandenburger and Nalebuff, 1996), which refers to the simultaneous practices of cooperation and competition practices. Besides the pooling of resources and the quest for synergistic effects (Das and Teng, 2000; Huang et al., 2009), co-opetition may also occur in the context of standard setting or when firms aim at jointly achieving a dominant design, which in turn fosters other innovations.

Cooperation with universities, research centres and the like has also been extensively studied, leading to mixed conclusions. On the one hand, cooperation with university and research centres have been identified as critical partners for the development of more radical or new-to-the-market innovations (Kaufmann and Tödtling, 200 I; Becker and Dietz, 2004). Some scholars have also concluded that cooperating with research institutions positively influence the so-called intermediary outputs of the innovation process, such as patents (e.g. Miotti and Sachwald, 2003). Lööf and Broström (2008) find that collaboration with university positively influences innovative performance of Swedish manufacturing firms and Aschhoff and Schmidt (2006) also evidence positive impact of university collaboration on the probability of developing new product at German firms. In the case of Dutch firms, Belderbos et al. (2004) find that R\&D collaboration with universities increases the growth of sales attributable to market novelties. On the other hand, some have argued that the knowledge developed by these partners is less likely to be applicable in the short term, and that they are frequently slow to react (Tether, 2002) and may not 
meet the needs of some industries, such as services industries (e.g.Tether, 2008). Dasgupta and David (1994) state that researchers in research centres and universities focus on academic results and they mostly ignore commercial results, leading to a negative impact on university cooperation. Pavitt (2003) focuses on the fact that the response time from universities may be slighter longer than what the business sector expects. According to Temel et al., (2013) cooperation with university doesn't bring expected benefit immediately and their findings prove that it takes a certain threshold of university collaboration intensity to reach a better performance.

Despite the growing body of literature on "open innovation" (Chesbrough, 2003), and the effects of opening up the innovation process on innovative and business performance, large-scale studies concentrating on qualifying and quantifying the impact of the openness nature of the innovation process remain scarce. This observation is further exacerbated when emerging economies are considered. Nevertheless, most prior studies focusing on manufacturing industries in developed economies tend to support a positive effect of cooperation on innovation performance, though to various forms and extents according to the type of partner or the cooperation intensity (e.g. Monjon and Waelbroeck, 2003; Tether, 2005; Tether and Tajar, 2008), our expectations naturally follow the same lines and we adopt an "a priori positive bias" of the effect of opening up the innovation process.

In sum, based on the arguments above we developed 10 hypotheses.

Hypothesis I: Cooperation with different partners has positive and significant impact on the propensity to develop and commercialise novel products.

Hypothesis 2: Internal R\&D which can be conducted either occasional or on a continuous basis has significant and positive impact on firm's innovation performance.

Hypothesis 3: Conducting simultaneously various types of innovations, namely process and organisational innovations, positively influences innovation propensity.

Hypothesis 4:The firm which has a marketing organization is more likely to introduce novelties

Hypothesis 5: There is a positive and significant correlation between size and innovation propensity.

Hypothesis 6: Collaboration with externally partners such as customers has a positive impact on firm's innovation propensity.

Hypothesis 7: Collaborating with externally partners like, universities has positive and significant effects on propensity to innovate.

Hypothesis 8: For the firms in emerging economies, having cooperation partners within the country has positive influence on the innovation propensity compared to coopera- tion with partners located abroad.

Hypothesis 9: Collaboration with suppliers has a positive impact on firm's innovation propensity.

Hypothesis 10: Collaboration with competitors has a positive impact on firm's innovation propensity.

\section{Data and method}

\section{Sample and data collection}

The empirical work is based on the Community Innovation Survey (CIS). The CIS is conducted by the Turkish Statistical Institute (TSI) and it is only available data source from the TSI that collects data in terms of the size of enterprises surveyed at country level and which is comprehensive in terms of the range of questionnaire items (e.g. innovation expenditures such as training expenditures or acquisition of external knowledge, importance of information sources and co-operation for innovation activities, factors hampering innovations and protection methods - patents but also trademarks, copyrights, design patterns and secrecy - for innovations).

The data covers all manufacturing sectors including small and large enterprises and the sampling excluded firms which have fewer than 10 employees over the period between 2006 and 2008. The survey has been conducted at enterprises' place by using face to face meeting and questions were answered by top level managers. A total of 5.863 companies responded to the survey. The average firm size has $247 \mathrm{em}$ ployees, whereas the median size is 49 and standard deviation is 1073 . Overall, $16 \%$ of firms are part of an enterprise group. According to the respondents, the main markets for their products and services was the local/regional market (56\% of respondents), followed by national market $(50 \%)$, and then to a lesser extent European countries (roughly $30 \%$ ) and all other countries (27\%) (Mention et al., 20l3).

The descriptive statistics indicate that slightly more than $8 \%$ of firms do cooperate to develop novelties, and that the main cooperation partner is located in the country $(7.8 \%)$, followed by European partners (4\%), US partners (1\%), Chinese and Indian partners (less than 1\%) and the rest of the world (I.I\%), whatever type of partner is considered (Mention et al., 2013).

\section{Measurement of variables}

In the survey, cooperation is defined as the "active participation with other enterprises or non-commercial institutions on innovation activities". Both partners do not need to gain a commercial benefit. The definition excludes pure contracting out of work where there is no "active co-operation." Cooperation partners include firms belonging to the same group; suppliers (Suppliers_ANY) of equipment, materials,

ISSN: 07 I8-2724. (http://www.jotmi.org)

Journal of Technology Management \& Innovation (c) Universidad Alberto Hurtado, Facultad de Economía y Negocios. 
components or software; customers (Customers_ANY) or clients; competitors (Competitors_ANY); universities and higher education institutions (Universities_ANY); consultants (Consultants_ANY), commercial labs or private R\&D institutes and finally, government bodies or public research institutes (Government_ANY).

Partners for innovation activities may be located inside the country (Cooperation _COUNT) or reside beyond boundaries, namely in other European countries (Cooperation_EU), United States (Cooperation_US), China (Cooperation _CHI) or India, and all other countries (Cooperation_REST). Cooperation is first modelled as an aggregated variable taking the value of $I$ if the firm cooperates, with any partner, located in any of the listed geographical areas. Then, we further delineate the type of cooperation partner in order to explore its impact on the propensity to innovate (measured as the introduction of new product, either goods or services) and then on the degree of novelty of the innovation.

We also investigate the role of the location of the partner in order to unveil if and to what extent this influences the outcome of the innovation process. All dependent variables related to cooperation (COOP_Type of partner and COOP geographical region) are binary, with values equalling when one when the firm does cooperate with this type of partner or with any type of partner located in this geographical area, respectively. We also include other variables, such as size (expressed in natural log), the ownership to a group and the fact that the firm declares conducting in-house R\&D activities on a permanent (R\&D_ Continuous) or on an occasional (R\&D_ Occasional) basis. Since literature has emphasized that the different forms of innovation are frequently intertwined, occur simultaneously, while supporting different strategic goals, we also include dummy variables related to the introduction of process (Process_Innovation), marketing (Marketing_Innovation) and organisational innovations (Organizational_Innovation).Across all multivariate analyses, innovation (INNO) is modelled as a dependent variable and equals one when the firm declares having introduced a new product (i.e. good or service). Logistic regression analysis is applied as it is often used to investigate the relationship between discrete responses and a set of explanatory variables (e.g. Cox and Snell, 1989; Agresti, 1990; Collett 199I; Hosmer and Lemeshow, 2000; Stokes et al., 2000).

\section{Results and discussion}

The first regression, which uses the variable COOP as an aggregate variable, clearly indicates that cooperation has a positive and significant influence on the propensity to develop and commercialise novelties (Table I). The value of the odds ratio confirms that cooperating strongly affects the probability to innovate, giving firms which set up cooperation agreements an advantage of almost 2.5 over firms which opt for a closed innovation process. This finding provides support for Hypothesis I. Results also provide support for Hypothesis 2 which indicates that doing intramural R\&D, either on a continuous or on an occasional basis significantly and positively impacts innovation performance. Comparing the odds ratios, firms that do R\&D on a permanent basis are much more likely to innovate than firms which conduct R\&D on an occasional basis. This is perfectly consistent with the extant literature on absorptive capacity (Cohen and Levinthal, 1989) and the need to maintain internal R\&D capabilities in order to integrate external knowledge into the internal innovation process. Interestingly, firms that declared

\begin{tabular}{|c|c|c|c|c|c|}
\hline $\begin{array}{l}\qquad \mathrm{DEP}=\mathrm{INNO} \\
\text { Intercept }\end{array}$ & $\begin{array}{c}\text { Parameter Esti- } \\
\text { mated } \\
-2.5247\end{array}$ & $\begin{array}{l}\text { Standard } \\
\text { Error } \\
0.1353\end{array}$ & $\begin{array}{c}\text { Khi2 } \\
348.3294\end{array}$ & $\begin{array}{c}\operatorname{Pr}>\text { khi2 } \\
<.0001\end{array}$ & Odds \\
\hline Group & -0.078 & 0.121 & 0.4162 & 0.5188 & 0.925 \\
\hline lnsize & -0.0121 & 0.0322 & 0.1415 & 0.7068 & 0.988 \\
\hline R\&D_Continuous $* *$ & 2.5474 & 0.1632 & 243.7552 & $<.0001$ & 12.774 \\
\hline R\&D_Occasional ** & 1.7629 & 0.1406 & $\mathbf{1 5 7 . 1 2 3 7}$ & $<.0001$ & 5.829 \\
\hline Process_Innovation** & 1.9385 & 0.0952 & 414.592 & $<.0001$ & 6.949 \\
\hline Marketing_Innovation* & 0.3268 & 0.1124 & 8.4493 & 0.0037 & 1.387 \\
\hline $\begin{array}{l}\text { Organizational_Innova- } \\
\text { tion** }\end{array}$ & 1.1664 & 0.1047 & 124.197 & $<.0001$ & 3.211 \\
\hline COOP & 0.8951 & 0.1551 & 33.3193 & $<.0001$ & 2.448 \\
\hline \multicolumn{5}{|l|}{ Percent Concordant 87.5} & \\
\hline
\end{tabular}

Table I - Role of cooperation on innovation propensity - ** $\mathrm{p}<0.01$; ${ }^{*} \mathrm{p}<0.05$

ISSN: 07I 8-2724. (http://www.jotmi.org)

Journal of Technology Management \& Innovation @ Universidad Alberto Hurtado, Facultad de Economía y Negocios. 
having introduced both process and organisational innovations are more likely to innovate than firms which do not succeed with or get involved in these innovation types and this is in parallel with Hypothesis 3.This finding supports the view that the different innovation types are closely linked and may be mutually supporting each other. Marketing organisation is also evidenced to be positively associated to product innovation, as the result is statistically significant at the $5 \%$ level and this result supports our statement in Hypothesis 4. Surprisingly, despite being statistically non-significant, size seems to negatively affect innovation propensity. This finding may seem contradictory with prior evidence supporting that larger firms are usually more likely to innovate.

As a second stage, the cooperation variable was disaggregated and we considered cooperation with each type of partner separately. These results replicate the pattern regarding the positive and significant influence of conducting R\&D activities either on a continuous or on an occasional basis (Table 2). Similar ranges for the odds ratios also confirm the magnitude of this influence. Likewise, conducting in parallel process, marketing and organisational innovations positively impact the propensity to develop novelties and this also in line in Hypothesis 4.

Process innovation clearly emerges as an enabler considering the value of the odds ratio. When focusing on the type of partner for cooperation activities, conclusions can be drawn only for customers or clients and for universities and higher education institutions as results are statistically significant only for these 2 types of partners. Cooperating with customers seems to give a clear competitive advantage when it comes to introducing product or service innovation and confirms prior research conducted in developed economies (e.g. Monjon and Waelbroeck, 2003; Tether, 2005) and this result supports Hypothesis 6. On the other hand, cooperation with the science base is demonstrated to negatively and substantively (considering that the odd ratio is much lower than I) influence the propensity to introduce novelties. Negative and significant effect of cooperating with universities has been found, with odds ratio value of 0.536 , suggesting a strong disadvantage of cooperating with this kind of partner for innovation activities. This result oddly suggests that cooperating with universities, whether they are located in the country or abroad actually deteriorates the innovation performance of the firm. As such, it is certainly challenging, and deserves further investigation in the context of the national innovation system as well as international academic cooperation. In conclusion, this finding does not support Hypothesis 7.

Adopting another angle to investigate the effects of cooperation, we merged the different partners according to their geographical origin. The results regarding intramural $R \& D$

\begin{tabular}{|c|c|c|c|c|c|}
\hline $\mathrm{DEP}=\mathrm{INNO}$ & $\begin{array}{c}\text { Parameter Esti- } \\
\text { mated }\end{array}$ & $\begin{array}{c}\text { Standard } \\
\text { Error }\end{array}$ & Khi2 & $\operatorname{Pr}>$ khi2 & Odds \\
\hline Intercept & -2.5482 & 0.1361 & 350.7409 & $<.0001$ & \\
\hline Group & -0.0651 & 0.1219 & 0.2854 & 0.5932 & 0.937 \\
\hline lnsize & -0.0073 & 0.0323 & 0.0522 & 0.8193 & 0.993 \\
\hline R\&D_Continuous** & 2.5948 & 0.1645 & 248.7145 & $<.0001$ & $\mathbf{1 3 . 3 9 3}$ \\
\hline R\&D_Occasional** & 1.7608 & 0.1409 & 156.0553 & $<.0001$ & 5.817 \\
\hline Process_Innovation** & 1.9723 & 0.0955 & 426.7989 & $<.0001$ & 7.187 \\
\hline Marketing_Innovation* & 0.3156 & 0.1131 & 7.7933 & 0.0052 & 1.371 \\
\hline Organizational_Innovation** & 1.1564 & 0.1052 & 120.7364 & $<.0001$ & 3.179 \\
\hline Group_ANY & 0.4313 & 0.302 & 2.04 & 0.1532 & 1.539 \\
\hline Suppliers_ANY & 0.0245 & 0.29 & 0.0072 & 0.9326 & 1.025 \\
\hline Customers_ANY* & 0.9878 & 0.3485 & 8.0337 & 0.0046 & 2.685 \\
\hline Competitors_ANY & 0.5143 & 0.3608 & 2.0312 & 0.1541 & 1.672 \\
\hline Consultants_ANY & -0.4939 & 0.3243 & 2.3196 & 0.1277 & 0.61 \\
\hline Universities_ANY & -0.6231 & 0.3775 & 2.7241 & 0.0998 & 0.536 \\
\hline Government_ANY & 0.6491 & 0.4076 & \multirow[t]{2}{*}{2.5366} & \multirow[t]{2}{*}{0.1112} & \multirow[t]{2}{*}{1.914} \\
\hline Percent Concordant & & & & & \\
\hline
\end{tabular}

Table 2 - Role of partner type on innovation propensity - ** $p<0.01 ;{ }^{*} p<0.05$

ISSN: 07 I8-2724. (http://www.jotmi.org)

Journal of Technology Management \& Innovation (C) Universidad Alberto Hurtado, Facultad de Economía y Negocios. 
again hold, as well as the mutually reinforcing effects of the different innovation types (i.e. marketing, organisational and process). Statistically significant results are obtained exclusively for cooperation within the country, which is evidenced to positively influence the propensity to innovate and this is in line with Hypothesis 8. Further delineating the cooperation with the different types of partners located in Turkey, positive and significant effects could be demonstrated for customers/clients and government bodies/public research institutes, with odds ratios of 3.235 and 2.168 respectively. Finding highlights that having external collaboration with all partners doesn't increase the likelihood to innovate in the emerging economy under investigation. Collaboration with suppliers and competitors is statistically not significant.

A further step included tests on whether cooperation, whatever the partner under consideration and its geographical location, had an impact on the degree of the novelty of the innovation. Namely, we tested whether cooperation affected the propensity to introduce new-to-the-market versus new-to-the firm innovations, as literature tends to suggest, although empirical evidence is scarce and usually ambiguous on this topic (e.g. Monjon and Waelbroeck, 2003; Mention, 20II). Results did not show any significant relationship between any type of cooperation (either horizontal or vertical cooperation forms) or the location of the partner and the degree of novelty, thus deserving further investigation.

\section{Conclusions}

Despite huge interest in developing the collaboration as a main accelerator for innovation propensity, few empirical studies have been used to examine the impact of collaboration on innovation propensity in emerging economies. In this exploratory empirical study based on $5.863 \mathrm{CIS}$ data from Turkey, which is one of the fastest growing economies last recent years we explored the effects of inter-firm, intrafirm, intra-country cooperation and cooperation with research actors. The findings revealed that as long as Turkish firms are involved in innovation activities either occasionally or continuously, they have better innovation performance. This would suggest that sequence of innovation activities does not really matter for innovation propensity as long as companies are involved any innovation activities in Turkey, whether they do it on a regular or irregular basis. With regards to the type of innovation it is evidenced that any type of innovation like process, organizational and marketing has a positive impact on Turkish firms' innovation propensity. However, process and organizational innovation has stronger impact then marketing innovation. Still it is clear that all type of innovation activities increase innovation skills of Turkish firms. Our results confirmed that collaboration is an important factor also for emerging economies for innovation propensity. Surprisingly only collaboration with customers may bring value to the innovation propensity of Turkish

\begin{tabular}{|l|c|c|c|c|c|}
\hline DEP=INNO & $\begin{array}{c}\text { Parameter } \\
\text { Estimated } \\
\text { Intercept }\end{array}$ & $\begin{array}{c}\text { Standard } \\
\text { Error } \\
0.5118\end{array}$ & $\begin{array}{c}\text { Khi2 } \\
\text { Pr> khi2 }\end{array}$ & Odds \\
\hline Group & -0.0889 & 0.1217 & 0.5333 & 0.4652 & 0.915 \\
\hline lnsize & -0.0145 & 0.0323 & 0.2003 & 0.6544 & 0.986 \\
\hline R\&D_Continuous ** & $\mathbf{2 . 5 4 6}$ & $\mathbf{0 . 1 6 3 7}$ & $\mathbf{2 4 1 . 8 0 8 5}$ & $<.0001$ & $\mathbf{1 2 . 7 5 6}$ \\
\hline R\&D_Occasional ** & $\mathbf{1 . 7 6 5 9}$ & $\mathbf{0 . 1 4 0 9}$ & $\mathbf{1 5 7 . 1 3 8 1}$ & $<.0001$ & $\mathbf{5 . 8 4 7}$ \\
\hline Process_Innovation** & $\mathbf{1 . 9 3 4 5}$ & $\mathbf{0 . 0 9 5 3}$ & $\mathbf{4 1 1 . 7 2 6 4}$ & $<.0001$ & $\mathbf{6 . 9 2 1}$ \\
\hline Marketing_Innovation & 0.3129 & 0.113 & 7.6701 & 0.0056 & 1.367 \\
\hline Organizational_Innovation*** & $\mathbf{1 . 1 6 4 1}$ & $\mathbf{0 . 1 0 4 9}$ & $\mathbf{1 2 3 . 1 0 0 1}$ & $<.0001$ & $\mathbf{3 . 2 0 3}$ \\
\hline Cooperation_EU & 0.4595 & 0.3186 & 2.0802 & 0.1492 & 1.583 \\
\hline Cooperation_US & -0.0235 & 0.5285 & 0.002 & 0.9645 & 0.977 \\
\hline Cooperation_COUNT** & $\mathbf{0 . 7 7 3 2}$ & $\mathbf{0 . 1 8 2 2}$ & $\mathbf{1 8 . 0 2 0 3}$ & $<.0001$ & $\mathbf{2 . 1 6 7}$ \\
\hline Cooperation_REST & 0.7795 & 0.5311 & 2.1538 & 0.1422 & 2.18 \\
\hline Cooperation_CHI & -0.3147 & 0.688 & 0.2093 & 0.6473 & 0.73 \\
\hline Percent Concordant & $\mathbf{8 7 . 8}$ & & & & \\
\hline
\end{tabular}

Table 3 - Role of geographical location of partners on innovation propensity - ** $p<0.01 ;{ }^{*}<<0.05$

ISSN: 07I 8-2724. (http://www.jotmi.org)

Journal of Technology Management \& Innovation (C) Universidad Alberto Hurtado, Facultad de Economía y Negocios. 
firms and this finding suggests that Turkish firms should pay accrued importance to their customers.

Astonishingly, and in contrast with previous studies (e.g. Capon et al., 1990; Lee et al., 200 I; Song et al., 2008), our findings reveal that collaboration with universities does not really enhance innovation propensity. Several reasons may explain this negative result. First, most of Turkish universities are teaching intensive. Second, there are few well functioning technology transfer offices and third, the absorption capacity of Turkish firms is very low. Another observation is the negative relationship between size and innovation propensity of the firm, although nothing can be concluded since the relationship is not statistically significant.

\section{Policy recommendations}

Based on the above analysis, policy recommendations for policy makers are as follows. It is obvious that all type of innovation initiatives improve innovation propensity of firms. Therefore it is important to urge firms to conduct innovation projects. Secondly, external collaboration is important factor and should be supported to extent firms' collaboration network via different mechanisms. Last but not least, university-industry collaboration does not create expected value in these types of countries, to the extent that our results show a negative relationship between university cooperation and innovation propensity. Therefore, new policies and instruments should be developed to have better results from this collaboration.

\section{Managerial implications}

The present article may help managers wishing to enhance their company's innovation propensity to take advantage of collaboration with external partners in emerging economies. However managers should keep in mind that the best partner for their innovation propensity is their customer and it is important to have well defined and long lasting collaboration with them. On the other hand, collaboration with research organization is not the best tool for innovation propensity in emerging economies since this collaboration needs longer period and firms in emerging economies cannot involve long time frame project due to their financial and technical restrictions. Therefore, managers should be very careful when they are choosing their innovation partners and also make sure that their firms ready for this collaboration. However, collaborating with local partners is much more beneficial than international collaboration for their firms.

\section{Limitations and future research}

This study focuses on a single country setting, which challenges the generalizability of the results. Nevertheless, due to the lack of prior empirical research on the effect of openness on innovation performance in emerging economies, this paper provides relevant insights into this critical issue. Using a longitudinal dataset would further allow capturing the dynamics of the innovation process and its effects on performance, and would thus significantly increase the relevance of these findings. Nevertheless, it should be mentioned that the data related to cooperation covers the entire period 20062008 while information on introduced novelties relates to 2008. Another interesting area for further development includes the collection of information on innovation as an object, as CIS is subject-oriented and thus focuses on the innovative activities of the firm, irrespectively of the importance of these activities. In other terms, CIS does not inquire whether one or several innovations have been introduced. Along the lines of prior projects such as those conducted by Pentikainen et al., (2002) in Finland, one could consider building such database focusing on novelties although this is a time-consuming and resource-intensive activity.

Avenues for further research include explaining some of the challenging results, especially when it comes to foreign cooperation when explored in an aggregated way. As Europe is by far the largest trade partner for the country, it would be relevant for policy makers and business leaders alike to understand the impact of developing synergies in innovation activities. Considering the critical role of innovation for economic growth, further understanding how cooperation affects performance so as to design effective and efficient innovation systems, at all levels - national, regional and local, with all related mechanisms and incentives should be of the utmost priority and may require the development of dedicated surveys in order to better capture the peculiarities of the innovation process and its openness nature in emerging economies.

\section{Acknowledgements}

The authors would like to thank Izmir Development Agency (IZKA) for its support and assistance to access the CIS data. The data was accessed during "Izmir Regional Innovation Strategy" project.

This paper is an extended version of the article entitled "Innovation and cooperation in emerging economies: two sides of the same coin?" accepted at the International Conference on Innovation and Entrepreneurship, Jordan, 2013. 


\section{References}

AGRESTI, A. (1990). Categorical Data Analysis. New York: John Wiley \& Sons, Inc.

AHUJA, G. (2000). The duality of Collaboration: Inducements and Opportunities in the Formation of Inter-firm Linkages. Strategic Management Journal, 2I, 3I 7-343.

ASCHHOFF, B., and Schmidt, T. (2006). Empirical evidence on the success of R\&D cooperation: happy together? ZEW Discussion Papers 06-59. ZEW-Zentrum für Europäische Wirtschaftsforschung/Center for European Economic Research.

BEBA, A., and Saatcioglu, K. (2009). Financing R\&D projects of innovative SMEs: National and International Funds. International Entrepreneurship Congress: SME's and Entrepreneurship (Ed: Katrinli), ISBN: 978-975-8789-32-0, 70-80.

BECKER, W., and Dietz, J. (2004). R\&D cooperation and innovation activities of firms - Evidence for the German manufacturing industry. Research Policy, 33 (2), 209-223.

BELDERBOS, R., Carree, M., Diederen, B., Lokshin, B., and Veugelers, R. (2004). Heterogeneity in R\&D cooperation strategies. International Journal of Industrial Organization, 22 (8-9), 1237-1263.

BRANDENBURGER, A.M., and Nalebuff, B.J. (1996). Coopetition. New York: Doubleday.

CAPON, N., Farly, J.U., and Hoenig, S. M. 1990. A meta-analysis of financial performance. Management Science, 16, II431159.

CETINDAMAR, D., and Ulusoy, G. (2008). Innovation performance and partnership in manufacturing firms in Turkey. Journal of Manufacturing Technology Management, 19 (3), 332-348.

CHESBROUGH, H. (2003). Open Innovation: The New Imperative for creating and profiting from technology. Harvard Business School Press: Boston, MA.

CINCERA, M., Kempen, L., van Pottelsberghe, B., Veugelers, R., and Villegas S. (2003). Productivity growth. R\&D and the role of international collaborative agreements: some evidence for Belgian manufacturing companies. Brussels Economic Review, 46 (3), 107-I 40.

COHEN, W., and Levinthal, D. (1989). Innovation and learning: the two faces of R\&D. Economic Journal, 99 (397), 569596.
COLLETT, D. (1991). Modeling Binary Data. London: Chapman and Hall.

COX, D.R, and Snell, E.J. (1989). The Analysis of Binary Data. Second Edition, London: Chapman and Hall.

CREPON, B., Duguet, E., and Mairesse, J. (1998). Research, innovation and productivity: an

econometric analysis at the firm level. NBER Working Paper Series, National Bureau of Economic Research, Working Paper: 6696.

DAHLANDER, L., and Gann, D. M. (2010). How open is innovation? Research Policy, 39 (6), 699-709.

DAS, T. K.., and Teng, B. S. 2000. A resource-based theory of strategic alliances. Journal of Management, 26 (I), 3I-6I.

DASGUPTA, P., and David, P.A. (1994). Toward a new economics of science. Research Policy, 23 (5), 487-52I.

FIOL, C. M. (1996). Squeezing harder doesn't always work: continuing the search for consistency in innovation research. Academy of Management Review, 2 I (4), I0I 2-102I.

GEORGE, V. P., and Farris, G. (1999). Performance of Alliances: Formative Stages and Changing Organizational and Environmental Influences. R\&D Management, 29, 379-89.

GRILICHES, Z. (1990). Patent Statistics as Economic Indicators: A Survey. Journal of Economic Literature, 28 (4), |66I1707.

HANNA, V., and Walsh, K. (2008). Inter-firm cooperation among Small Manufacturing Firms. International Small Business Journal, 26, 299-32I.

HOSMER, D.W, Jr., and Lemeshow, S. (2000).Applied Logistic Regression. Second Edition, New York: John Wiley \& Sons, Inc.

HUANG, Y.A., Chung, H. J., and Lin, C. (2009). R\&D sourcing strategies: Determinants and consequences. Technovation, 29 (3), I55-169.

KABIRAJ, T., and Yang, C. L. (200I). Licensing vs. Innovation incentives uncertain government policies. International Review of Economics and Finance, 10, 247-26 I

KAUFMANN,A., and Tödtling, F. (200I). Science-industry interaction in the process of innovation: The importance of boundary-crossing between systems. Research Policy, 30 (5), 79I-804. 
LAURSEN, K., and Salter, A. (2006). Open for innovation: The role of openness in explaining innovation performance among U.K. manufacturing firms. Strategic Management Journal, 27 (2), | $3|-| 50$.

LEE, C., Lee, K., and Pennings, J.M. (200I). Internal capabilities, external networks, and performance: a study on technologybased ventures. Strategic Management Journal, 22, 615-640.

LICHTENTHALER, U. (20II). Open innovation: Past research, current debates, and future directions. Academy of Management Perspectives, 25 (I), 75-93.

LOOF, H., and Broström, A., (2008). Does knowledge diffusion between university and industry increase innovativeness? The Journal of Technology Transfer, 33 (I), 73-90.

LOOF, H., and Heshmati, A. (2002). Knowledge capital and performance heterogeneity: a firm-level innovation study. International Journal of Production Economics, 76 (I), 6I-85.

MAIRESSE, J., and Mohnen, P. (200I).To be or not to be innovative: an exercise in measurement. STI Review 27, 103-128.

MENTION, A.-L. (20II). Co-operation and co-opetition as open innovation practices in the service sector: which influence on innovation novelty? Technovation, 3I(I), 44-53.

MENTION, A.खL., and Asikainen, A.खL. (2012). Innovation \& Productivity: investigating effects of openness in services. International Journal of Innovation Management, 16 (3), DOI: I0.I|42/SI3639|96I240004X.

MENTION, A.-L., Temel, S., and Torkkeli, M. (20I3). Innovation and cooperation: two sides of the same coin, Accepted (conditionally). International Conference on Entrepreneurship and Innovation, Amman, March 2013.

MIOTTI, L., and Sachwald, F. (2003). Co-operative R\&D:Why and with whom? An integrated framework of analysis. Research Policy, 32 (8), I48I-I499.

MONJON, S., and Waelbroeck, P. (2003). Assessing spillovers from universities to firms: Evidence from French firm-level data. International Journal of Industrial Organization, 2 I (9), |255- 270.

MOOKHERJEE, D., and Ray, D. (199I). On the competitive pressure created by the diffusion of innovations. Journal of Economic Theory, 54 (I), I24-I 47.

PAMUKCU, T. (2003). Trade Liberalization and Innovation Decisions of Firms: Lessons from Post- 1980 Turkey. World Development, 3 I (8), I 443-I458.
PAVITT, K.. (2003). The Process of Innovation. SPRU Electronic Working Paper Series No. 89.

PENTIKÄINEN, T., Palmberg, C., Hyvönen, J., and Saarinen, J. (2002). Capturing innovation and recent technological change in Finland through micro data elaborating on the object approach. Unpublished Mimeo,VTT Technology Studies.

ROTHWELL, R. (1992). Successful industrial innovation: critical factors for the 1990s. R\&D Management, 22, 22I-239.

SCHUMPETER, J. A. (1942). Capitalism, Socialism and Democracy. London: Unwin.

SONG, M., Podoynitsyna, K., Van Der Bij, H., and Halman, J.I.M. (2008). Success factors in new ventures: $A$ meta-analysis. Journal of Product Innovation Management, 25 (I), 7-27.

STOKES, M.E., Davis, C.S., and Koch, G.G. (2000). Categorical Data Analysis Using the SAS System. Second Edition, Cary, NC: SAS Institute Inc.

TAYMAZ, E. (2009). Development strategy and evolution of Turkey's innovation system', in: J.H. Suh (Ed) Models for National Technology and Innovation Capacity Development in Turkey, 63-104 (Seoul: Korea Development Institute).

TEMEL, S., Scholten,V.,Akdeniz, R.C., Fortuin, F., and Omta, O. (20I3). University - Industry Collaboration in Turkish SME's: Investigation of a U-shaped relationship. International Journal of Entrepreneurship and Innovation, 14 (3).

TETHER, B.S. (2002). Who co-operates for innovation, and why. An empirical analysis. Research Policy, 31, 947-967.

TETHER, B. S. (2005). Do services innovate (Differently)? Insights from the European innobarometer survey. Industry and Innovation, 12 (2), I53-184.

TETHER, B. S., and Tajar, A. (2008). Beyond industry-university links: Sourcing knowledge for innovation from consultants, private research organizations and the public sciencebase. Research Policy, 37 (6-7), 1079-1095.

TURKOGLU, M., and Celikkaya, S. (20I I). R\&D Support for Small and Medium Size Enterprises. International Journal of Alanya Faculty of Business, 3 (2), 56-7I.

VAN DE VRANDE, V., de Jong, J. P. J., Vanhaverbeke, W., and de Rochemont, M. (2009). Open innovation in SMEs:Trends, motives and management challenges. Technovation, 29, (6-7), 423-437. 
YANIKTEPE, B., and Cavus, M.F. (20II). Investigation of policy and incentives on the industrial research and development in Turkey. African Journal of Business Management, 5, (22), $9214-9223$. 